\title{
ESCREVENDO-SE MULHER: UM DIÁLOGO ENTRE A CRÍTICA FEMINISTA E A LÍRICA DE MARIA TERESA HORTA
}

\section{WRITING ONESELF AS A WOMAN: A DIALOGUE BETWEEN FEMINIST CRITICISM AND THE POETRY BY MARIA TERESA HORTA}

\author{
Natália Salomé de SOUZA ${ }^{1}$ \\ Vinícius Carvalho PEREIRA²
}

\begin{abstract}
Resumo: Maria Teresa Horta, poetisa portuguesa contemporânea, faz de sua lira um exercício do que a crítica feminista convencionou chamar de écriture féminine, ou escrita feminina. Suas escolhas estéticas são, pois, escolhas também políticas, em que a poesia se constrói a partir do corpo numa busca do sentido do ser mulher. Perquirição identitária no seio da linguagem, os poemas da autora se constituem como experiências eróticas de autoconhecimento, em que a mulher possa se entender como positividade, e não como negação do masculino. No presente artigo, colocam-se em diálogo teorias da crítica feminista e alguns textos da obra de Maria Teresa Horta, a fim de melhor compreender como
\end{abstract}

\footnotetext{
${ }^{1}$ Graduada em Letras (UFMT), Mestranda do Programa de Pós-Graduação em Estudos de Linguagem (UFMT) - natsalome@gmail.com

2 Doutor em Ciência da Literatura (UFRJ) e professor do Departamento de Letras e do Programa de Pós-Graduação em Estudos de Linguagem (UFMT) viniciuscarpe@gmail.com
} 
a escrita feminina da autora (e por que não da eu-líricA?) pode ser metonímia de uma busca de todas as mulheres por um espaço de diferença sexual - inalienável do gozo, da letra, do poema.

Palavras-chave: Maria Teresa Horta. Crítica feminista. Écriture féminine.

\begin{abstract}
Maria Teresa Horta, a contemporary Portuguese poet, exercises in her poetry what feminist criticism calls écriture féminine, or women's writing. Therefore, her aesthetic choices are also political, whereby poetry comes up from a quest for what it means to be a woman. In a search for identity within the realm of language, the poems by this writer are erotic experiences of self-knowledge, where the woman can be understood as something positive, not as a negation of masculinity. In this paper we propose a dialogue between theories from feminist criticism and some texts by Maria Teresa Horta, to better understand how the author's feminine writing (and why not the writing of a feminine lyrical-I?) can be a metonymy of all women's quest for a space of sexual difference - inextricable from joy, letter and poetry.
\end{abstract}

Keywords: Maria Teresa Horta. Feminist criticism. Écriture féminine.

\title{
Introdução
}

Mulher, mulher, mulher. Talvez nos dissessem que devêssemos usar um dicionário de sinônimos para evitar a repetição desnecessária. Necessária para nós. Mas se nos deixamos dominar pela lógica falogocêntrica, mantemo-nos na busca pelo nome: recusamo-nos à busca dos falsos sinônimos. Ser mulher não cabe no nome, não é captável pelos nomes. É inominável, é fluido e circular. Retorna a si mesma, assim como a escrita, porque se toca, leve, intensa, repetidamente. Se reescreve! Se inscreve: no corpo.

É através da lógica da não presença que a mulher se mantém presa, mas e se usar essa mesma lógica para se libertar? E se for no interdito - para os ouvidos e olhos masculinos - que sua música 
se faz? Parler femme ${ }^{3}$... falar: mulher. São tantas e são diversas. Diversas em si, diversas deles - e não como retrato dele ou dela, mas como celebração da diferença que não se compara. Não vemos a diferença pelo negativo: não é pela falta do falo, é na positividade da fala - multiplicidade que a mulher encarna e de que é a diferença. "Porque o que eu quero, de fato, não é criar uma teoria da mulher, mas assegurar um lugar para o feminino dentro da diferença sexual." (IRIGARAY, 1985, p. 159).

Nesse contexto, na dilemática empreitada de um artigo a quatro mãos, em que uma mulher e um homem se põem a escrever, na fluidez polifônica desse discurso acadêmico (mas também poético), pomonos a analisar, sob a ótica da crítica feminista, a produção poética de Maria Teresa Horta. Homem e mulher a falar de mulher, Academia e poesia a falar de literatura: a crítica feminista como exercício de metalinguagem política. Neste artigo, exercitamos, pois, um diálogo da diferença, em que uma escrita feminina, que fala pela pele, pelos poros, pelos lábios da primeira autora, é acolhida, hibridizada mas nunca assimilada - pela voz de seu coautor masculino, a fim de melhor compreender a écriture feminine de Maria Teresa Horta.

A écriture feminine, como nos diz Cixous (2007) é aquela que parte do corpo, mas de um corpo que se conhece e se reclama. Não é o corpo que vem sendo representado ao longo dos séculos, que é milimetricamente detalhado, observado e definido, e sim o corpo que vem ganhando espaços no ser mulher. No corpo que reconhece em si o próprio gozo e a própria dor. Na escrita feminina, a mulher se insere na linguagem e a transforma para que esta possa ser verdadeiramente sua. Não é mais o padrão, a forma, a regularidade masculina que está em vigor, mas o corpo da mulher, fluido como sua fala, intenso tanto quanto seu gozo, que encontra um fim em si próprio, o qual está inscrito nessa escrita. A mulher se escreve e inscreve dando forma a si própria para mostrar que está presente, e que dessa forma se marcará na história, na sociedade.

\footnotetext{
${ }^{3}$ Ao longo artigo, traduz-se essa locução cunhada por Irigaray (1985) como "falar (como) mulher".
} 
Sendo, pois, essencialmente poética essa escrita feminina, colocamos em diálogo neste artigo as produções líricas de Maria Teresa Horta, poetisa portuguesa contemporânea, e algumas teorias da crítica literária feminista, que entendem o ato da escrita poética como escrita também do ser mulher. Assim, discutimos aqui como se dá na superfície do corpo a escrita feminina que reclama para si a materialidade do procedimento poético: corpo do texto e corpo da mulher imbricam-se num jogo erótico, em que o gozo devém lírico e a mulher se funda no real e no simbólico.

Tal pesquisa se justifica sob dois vieses complementares: o acadêmico-estético e o sociopolítico. Por um lado, a análise da poesia de Maria Teresa Horta à luz de teorias feministas preenche uma série de lacunas exegéticas nos estudos de literatura portuguesa contemporânea, lançando nova luz sobre uma autora de vasta produção, ainda que duplamente marginalizada pelo cânone - na condição de mulher que escreve sobre a experiência de ser mulher. Por outro lado, o artigo que aqui se delineia é ação política ao ampliar a noção de pós-colonialismo, fazendo do estudo de poesia uma práxis decolonizadora, que permite ao oprimido dizer(-se) (SPIVAK, 1988).

A esse respeito, somem-se alguns dados da biografia da autora cuja obra ora se analisa. Maria Teresa Horta combateu o silêncio da ditadura militar em Portugal ao dar-se voz através de sua poesia erótica, que faz do corpo da mulher instrumento de libertação de si. Repreendida, investigada, julgada e agredida não apenas pelo poder ditatorial de Marcelo Caetano, mas também pelos membros da sociedade patriarcal em que se inseria, a poetisa foi surrada na rua quando da publicação do livro Minha Senhora de Mim (HORTA, 1971). Na publicação de Novas Cartas Portuguesas (BARRENO, COSTA, HORTA, 1974), foi levada a julgamento junto a Maria Isabel Barreno e Maria Velho da Costa, coautoras da obra, por incitarem a emancipação da mulher. No corpo, as chagas da luta que se transplantam como violência e sublevação em sua écriture féminine.

De relevância para a academia enquanto extrapolação do 
cânone e para a afirmação política da mulher, o estudo da poesia de Maria Teresa Horta se justifica também na imanência do texto da autora. Extremamente lírica, sua poesia põe em questão o que é escrever e como este ato confunde-se com o escrever-se. Na página ou na pele - escrivaninha do corpo em que a poesia feminista se dá -, é essa condição da escrita feminina como autoconhecimento e emancipação pelo gozo que o presente artigo visa analisar.

\section{Escrevendo-se mulher pelo corpo}

Encontrar o lugar do feminino dentro da diferença sexual é um grande passo para mudanças da percepção do local da mulher na cultura, na sociedade e na economia. Inseri-la nos espaços através de uma perspectiva que não seja da similitude é, pelo menos, ousado. A similitude levaria a mulher a uma comparação direta com o homem, ou seja, procuraria moldá-la de acordo com as características que a assemelham e a afastam da figura masculina. Dentro dessa perspectiva, existe uma relação hierárquica que prevê que o homem é o padrão, a norma; por isso, diferir dele equivalia a ser-lhe inferior, segundo a lógica do patriarcado.

Tendo seus corpos aprisionados nessa ideologia em que a centralidade está na imagem do falo, as mulheres foram representadas ao longo do tempo de diversas formas que oprimiam sua própria chance de imanência - e talvez de essência -, problema que cabe também aos estudos literários investigar e denunciar. A escrita, como sinal da materialidade, do deixar marcas no mundo, tradicionalmente captou o que a mulher não era e, a partir dessa política da negatividade, não permitiu que a mulher entendesse/ sentisse suas próprias potencialidades.

Assim, as poucas mulheres a quem foi dado o direito de escrever convencionalmente tiveram de fazê-lo dentro de uma linguagem que não era a sua, de um dispositivo discursivo que não as integrava, que não as via e onde elas não cabiam. A mulher só pôde escrever dentro do falogocentrismo (DERRIDA, 1981); dominada pela lei do 
falo - do Pai, e não da Mãe - e pela lei do logos ocidental, ela se emaranhou (ou foi emaranhada) dentro de uma teia cada vez mais fechada onde se tornou uma sombra do que poderia vir a ser.

Desse modo, passou a escrever, mas continuou a se representar (e ser representada) através de um mundo que não era seu. 0 logos mantinha e estabelecia a visão e a intenção do homem sobre o corpo da mulher, a respeito da alma da mulher, acerca de uma cultura, sociedade e economia - que não eram da mulher. A escrita por meio das mãos que perpetuaram a dominância do falogocentrismo procurou moldar o ser mulher no interior da linguagem patriarcal. Do falo à fala realmente feminina há, então, um hiato, que custou à literatura atravessar.

Maria Teresa Horta, em plena ditadura portuguesa, lançou-se a esse desafio, em uma escrita poética que lhe brota das entranhas do corpo, das cavidades mais íntimas em que se institui no mundo e na sociedade como mulher. Em ato libertário, escreve para ver a si prescindindo dos olhos do homem e da ideologia fascista do Estado Novo.

No governo de Marcelo Caetano, o regime opressor transpunha para a instância da família a lógica de uma sociedade organizada pelo medo, em que à mulher caberia a preservação do lar, metonímia da nação. Nessa perspectiva, a mulher deveria ser mãe, acima de tudo; o que lhe cabia era cuidar dos filhos e do marido, sua pequena pátria a defender. Sua vida sexual e seu desejo deveriam ser trancafiados dentro de seus corpos, sob o peso e a repressão da pátria: falar sobre isso era ultrapassar os limites da moral e da religião.

Do mesmo modo como essa mãe portuguesa, podemos pensar o discurso que ronda na sociedade tradicional todas as mães: as esposas-mães, as mulheres-mães, as amantes-mães, as irmãs-mães, as primas-mães, as rainhas-mães, as santas-mães, as putas-mães e as bruxas-mães.

Para a lógica machista, todas essas mães exercem sua função e nela se descontentam. Aquelas que recusaram a maternidade 
foram taxadas como histéricas, doidas, bandidas e banidas de uma convivência social porque lhes restava o lugar do ninguém: ao não serem mães, jamais conseguiriam a entrada no simbólico por meio da projeção de um falo próprio (o bebê). Essa é uma forma curiosa (para usar as palavras de maneira mais branda) de enxergar a mulher: como sua imagem na sociedade é a do não homem, carregada de negatividade, ela representa o papel que o homem lhe deu: o papel materno que lhe proporciona uma vida de cuidado e de castidade e lhe dá um arremedo do falo castrado, sob a forma de um filho. É apenas através do falo que a mulher alcança um status dentro da sociedade.

Contudo, isso não é ser mulher. E então, o que é ser mulher? Simone de Beauvoir (1980) afirma que não se nasce mulher, tornase mulher. Luce Irigaray (1985) assevera que a mulher, na entrada ao simbólico, já se relaciona com o mundo de forma diferente, por isso já é mulher - com o que Irigaray não pretende entrar no reino dos binarismos. Na verdade, essa entrada no simbólico, quando comparada com a entrada do homem, demonstra a multiplicidade e mobilidade da mulher. 0 gesto da mulher difere do gesto do homem e pode ser entrevisto, em sua dinâmica fluida no poema a seguir, em que a escrita de Maria Teresa Horta se constrói como movimento em direção a uma identidade, busca de si que não se cristaliza em um precipitado, mas faz ressoar, na própria significação, reverberações do tornar-se mulher.

Minha memória cetim

À minha mãe

Minha mãe

mulher-infância

meus cabelos revoltados

minhas longas pernas nuas

meu espelho desirmanado 


\section{Minha mãe \\ mulher-infância \\ com sua pele marfim \\ minha água de beber \\ minha memória \\ cetim \\ (HORTA, 1983, p.59).}

A aproximação entre mãe e filha no poema é apresentada numa relação de similaridade, em que o hífen do neologismo "mulher-infância" funciona como espelho entre os vocábulos. 0 sinal diacrítico, enquanto lâmina refletora, faz da justaposição morfológica um processo de equalização, em que a semelhança entre as mulheres torna o laço mãe-filha mais forte.

É curioso o quanto essa união é vital, pois a mãe se torna "água de beber", ou seja, além de dar a vida, ela a mantém. A delicadeza desse laço se exprime na imagem "minha memória/cetim": o toque macio do tecido é traço mnêmico dessa relação, que se dá no nível da sensação e do sentimento. É na infância que esse vínculo se torna vital, ou seja, na entrada numa ordem simbólica que alça outros voos que não os da Lei do Pai.

Nessa perspectiva, Luce Irigaray (1985) afirma que se faz fundamental a percepção dessa outra ordem simbólica, não masculina, na qual a mulher viva em plenitude a partir de si mesma ou da identificação especular com a mulher primeira - a mãe. Em "Minha memória de cetim", essa dinâmica de reflexos e imagens se presentifica no verso "meu espelho desirmandado" e na própria estruturação das estrofes, em que os versos se relacionam por parataxe, e não hipotaxe. Sem subordinação sintática, as imagens de "Minha mãe", "mulher-infância" e "meus cabelos revoltados" se relacionam por similaridade, em que a filha, a mãe, a infância se tornam instâncias híbridas, no difuso e inefável ser mulher. Desse modo, o poema que se endereça à mãe, na figura do apóstrofe que o abre, pode ser lido como poema que se endereça à própria eu- 
lírica ${ }^{4}$, já que uma mulher é sempre todas as mulheres, constituídas no simbólico por essa identificação mútua.

Notemos: embora a entrada da mulher no simbólico seja diferente da do homem, ela é enlaçada pela história e cultura patriarcais de tal forma que não lhe é permitido vivenciar sua multiplicidade, de modo que ela acaba entrando nos moldes do simbólico masculino. É nesse ponto que Irigaray propõe toda uma mudança - quase uma luta solitária - para que a mulher se empodere como tal e consiga viver na mesma casa com o homem: uma casa de celebração da diferença.

Nessa mudança de ordem simbólica proposta por Irigaray, não se deveria relacionar a mulher ao falo, à falta; ou seja, à visão de que ela é mulher por não ser homem. Ela deveria ser vista como mulher, um sujeito completamente independente da subjetividade e objetividade biológica, social, econômica e histórica do homem. Belamente, ao descrever o simbólico feminino, Irigaray introduz a metáfora dos dois lábios: ao se tocarem, os lábios permitem uma série de prazeres que só são possíveis por haver dois, dois que representam um. Lábios que não se separam da boca, da língua, da fala, e portanto da poesia, como nos revela a lírica de Maria Teresa Horta.

É a partir desse movimento de se perceber, de entender a sua própria relação com o mundo, seu corpo e outros corpos, que a mulher conseguirá se desvencilhar das amarras do logocentrismo fálico e produzir um discurso embasado em si e em sua interação com o seu próprio simbólico. A mulher, por estar constantemente se tocando - uma vez que sua genitália possui um formato de dois lábios que estão em contínuo contato e não precisam de um

\footnotetext{
4 Termo aqui propositalmente flexionado no feminino, demarcando morfologicamente uma posição ética e estética. Afirmar que a mulher se insere na escrita não significa que Maria Teresa Horta em seu poema escreva suas experiências pessoais, e sim que transforma o seu ser em poesia. Há sim o corpo da mulher na escrita, mas este não é a materialidade do corpo da autora. 0 uso do termo "eu-lírico" nesse trabalho nos levaria a um apagamento do sujeito feminino e um enraizamento na lógica do falogocentrismo; portanto, subverter o termo e usá-lo num jogo de linguagem que o transforma em feminino realiza melhor o gesto crítico deste artigo.
} 
mediador para se tocarem (IRIGARAY, 1985) -, possui outras formas de relação consigo mesma que não são possíveis para o homem.

Irigaray relaciona a entrada da mulher no simbólico ao processo da fala, mas de uma fala que é emitida também como canção. Esse canto/fala vai se utilizar dos lábios inteiros e não de parte deles, como acontece no mecanismo do fort-da masculino. A partir dos lábios bucais, a interação da fala feminina se faz com todo o corpo, pois "os lábios são a própria mulher" (IRIGARAY, 1997, p. 183), em jogo erótico entre língua e cavidade bucal, lábios e cavidade genital - gozo a que se dá o poema a seguir:
A BOCA - OS LÁBIOS
A boca
os lábios
o labirinto dos dentes
que a saliva procura
na vagina da face

(HORTA, 2012, p. 92).

No poema "A Boca - Os lábios", a eu-lírica torna imagética essa multiplicidade do sentir feminino, em que todo o corpo está ligado às sensações e como um todo produz e recebe o gozo. Não se encaixa, portanto, na metafísica da presença e ausência masculinas, visto que não é a partir de um ponto único e ereto que a mulher experimenta o seu prazer, tal como o homem que goza centrado no falo.

O poema exprime com primazia a relação dos dois lábios postulada por Irigaray (1985), pois estes são tanto os lábios bucais - por onde a mulher entra no simbólico com sua fala, sendo capaz de trazer algo de dentro para fora - quanto são os lábios vaginais, uma das várias possibilidades de prazer sexual feminino, num movimento de fora para dentro. 0 dístico da primeira estrofe, que encerra dois versos com mesma estrutura sintática (artigo definido e substantivo concreto), sublinha essa semelhança entre a boca e a vulva, de modo que os dois versos funcionem como o par de lábios que ensejam o beijo, a fala, o gozo na "vagina da face". 
Irigaray ressalta a importância da imagem dos lábios quando diz que

forçar uma mulher a falar ou forçar uma mulher deitada a abrir os lábios, a sair de si mesma, pode representar uma violação analítica. A mulher não está protegida pelo mecanismo do fort- $d a$, pela maneira como este está constituído por divisões de tempo, de espaço, do outro, do eu, por suas divisões fonéticas. Com muita frequência ela é incapaz de se expressar, a não ser que, para começar, seus lábios novamente toquem um no outro e ela movimente o corpo todo. (IRIGARAY, 1997, p. 184).

Portanto, quando os lábios se movem, mexem com todo o corpo e, quando uma mulher fala, espontaneamente, ela se diz por inteira, entregando-se no ato do dizer. 0 corpo da mulher, como estrutura, assemelha-se então ao poema, em que o todo ultrapassa a soma das partes e tem uma dimensão intangível, que a interpretação, o amor, a exegese tentam fazer falar.

Ainda no poema "A boca - os lábios", a interação de todo o corpo se faz presente, pois, embora os lábios estejam distantes como partes do corpo, são boca e vagina ao mesmo tempo; já não importa onde o corpo se toca, pois o toque é total. A metáfora apresentada como a "vagina da face" é fortemente marcada por uma sexualidade feminina devoradora, uma vez que os dentes nos remetem à imagem da mastigação, trituração. Mas eles aqui se apresentam como labirintos percorridos pela saliva, aproximando o ser feminino ao elemento aquático de onde sua fluidez emana. A mulher, como um rio, não pode ser contida numa margem - a mulher transborda no gozar.

Cabe lembrar aqui que a "vagina dentada" é arquétipo que aterroriza os homens pelo seu poder de castrá-los. No entanto, se observarmos mais atentamente esse órgão erógeno feminino, podemos entendê-lo em relação a si próprio - e não como em função (ou oposição) do falo a ser castrado -, na circularidade que é característica da mulher. Observar o corpo da mulher em 
relação a ele próprio retira-lhe a função que exerce no mundo do falo: a vagina dentada não servirá de reguladora sexual masculina e não representará a mulher como descontrolada sexualmente devoradora de homens. A vagina não pertence à Lei do Pai.

Podemos observar essa relação da vagina estritamente com o corpo feminino, ainda que numa perspectiva do devorar, no poema a seguir:

\author{
A VAGINA \\ É cálida flor \\ e trópica mansamente \\ de leite entreaberto às tuas mãos \\ Feltro das pétalas que por dentro \\ tem a felpa das pálpebras \\ da língua a lentidão \\ Rosa do corpo \\ pulmão que não respira \\ dobada em cuspo tecida a sua água \\ Flor carnívora voraz do próprio suco \\ no ventre entorpecida \\ nas pernas sequestrada \\ (HORTA, 2012, p. 117).
}

Iniciado pelo verbo "ser", o corpo do poema se inscreve como explicação ou definição do seu título, movimento metalinguístico em que, por meio da poesia, a mulher busca entender a si, seu sexo, parte de si que lhe foi alienada pelo olhar fetichista e repressor de um outro que a oprime. Nessa perquirição por um significado da vagina, o poema a descreve por meio de imagens altamente sinestésicas, em que a eu-lírica prioriza o sentido do tato nas texturas, temperaturas e movimentos, aumentando a carga erótica da lira sem recair na pornografia que separa a mulher de seu sexo e a reifica para consumo alheio. 
No poema, a vagina é representada de forma ambivalente, entre a flor mansa e a boca ávida, instâncias que se encontram no último verso, na imagem da flor carnívora. Úmida, macia e cálida, a flor bucal - ou boca floral - é vagina que seduz e acaricia; todavia, o objeto da carícia é aqui o próprio corpo da mulher, num movimento reflexivo e autoerótico que se entrevê nos versos "dobada em cuspo tecida a sua água", "no ventre entorpecida" e "nas pernas sequestrada".

Desse modo, o que a flor devora no poema não é o pênis, como no mito da vagina dentada. Ela existe para si mesma, e não para ameaçar o homem; logo, é do seu próprio suco que tal vagina é voraz. Sorver a si mesma é lamber-se na língua - e no verso -, num exercício de a mulher olhar a si própria na instância do poema: "tem a felpa das pálpebras/ da língua a retidão".

Não estando a ferocidade da flor-vagina ligada a uma regulação sexual com o homem, mas sim ao corpo da própria mulher, a busca por uma identidade na escrita feminina devém uma fome de si. Tal necessidade de seu corpo se transfere para a poesia, do mesmo modo como Hélène Cixous (1987) proclama que a mulher deve se escrever com todo o seu corpo.

A mulher deve se escrever: deve escrever sobre mulher e trazer a mulher para a escrita, de onde elas foram retiradas tão violentamente quanto de seus corpos pelas mesmas razões, através da mesma lei, e com o mesmo objetivo fatal. A mulher deve se colocar no texto como no mundo e na história - por sua própria ação. (CIXOUS, 1987, p. 320).

Ou seja, é através de si mesma, do conhecimento do seu próprio corpo, do autoerotismo e do seu preciso - e precioso - ser que a mulher deve elaborar sua escrita, para que dessa forma ela seja inserida na história por meio do que é e não da forma em que é representada pelos homens. A escrita feminina, como escrita do corpo, torna-se uma ferramenta de empoderamento da mulher, em que esta se afirma numa nova linguagem. 
Contudo, quando o corpo feminino é definido através de um modelo falogocêntrico, seu valor fica inscrito nos de uma sociedade patriarcal, onde o que importa é a propriedade, o domínio dos meios de produção, a ordem, a forma, a ereção (IRIGARAY, 1985). É a dinâmica do sólido e não da fluidez que domina no falocratismo.

É dentro dessas tradições falogocêntricas que a psicanálise tradicional entende o desenvolvimento da sexualidade feminina. Logo, segundo Irigaray (1985), na leitura psicanalítica conservadora, não haveria dois sexos, mas apenas um, de modo que a sexualidade feminina seria definida, modelada e inserida dentro das exigências da sexualidade masculina. Nessa perspectiva, tudo o que se refere à mulher se define pelo complexo de castração, pois não haveria uma superação do complexo de Édipo, da inveja do pênis, e ter um filho seria supostamente a única forma de preencher o vácuo causado pela falta do falo.

Quando Lacan leva a psicanálise para o nível do discurso, revela-nos que é na linguagem que se estabelecem as questões da sexualidade, transformando a maneira de enxergar o ser humano. Contudo, Irigaray (1985) não nos deixa esquecer que tais leis da linguagem foram por séculos também definidas pelos homens; fascista (BARTHES, 1994), a linguagem tradicional existe dentro dos padrões masculinos definidos ao longo da existência da humanidade.

Irigaray, para explicar essa visão da psicanálise, cita Lacan e seu seminário XX:

Não há mulher que não esteja excluída da natureza das coisas, que é a natureza das palavras, e temos que dizer que, se há algo que elas lamentem bastante no momento, é mesmo disso - exceto que elas não sabem o que estão falando, esta é toda a diferença que há entre elas e eu. (LACAN apud IRIGARAY, 1985, p. 87).

Quando Lacan diz que as mulheres não sabem o que dizem, é pelo fato de que elas não possuem um lugar privilegiado na linguagem: 
a mulher não existiria na linguagem, embora esteja dentro dela. Há algo no mundo feminino e no seu prazer que escapa à compreensão da lógica linguística. A exclusão feminina seria então inerente à linguagem e por esse motivo a mulher é uma ameaça: ela desafia a ordem pela potência em subvertê-la.

Segundo tal perspectiva, no simbólico a mulher é um "not-all" (não toda), uma vez que o todo é o homem. Ela não é e não vai ser sujeito, não entra num molde universal, a menos que adquira e se entranhe nas necessidades masculinas e a partir delas se defina no único lugar que lhe resta: o da mãe. A necessidade de possuir o falo - a inveja do pênis - representaria a vontade feminina de entrar na ordem simbólica, mas ela só faz parte dessa ordem quando abre mão da sua feminilidade. Dessa forma, seria como se, quando a mulher entrasse no simbólico, perdesse suas características femininas, a ponto de não existir de forma corporal. Ela não seria definida afirmativamente pelo corpo e sim negativamente por essa falta que representa na linguagem.

Nessa descorporeificação da mulher, sua sexualidade é deixada de lado no discurso, uma vez que ela atende às necessidades masculinas. Já não interessam quais são as regiões erógenas das mulheres, pois elas, em verdade, não existem: a mulher não sabe falar sobre o prazer, uma vez que não compreende a linguagem; a ela falta a palavra.

E quando se fala na vivência do prazer, o "Um", ou o todo, só sentiria prazer ao conhecer as partes do corpo do "Outro" que não fazem parte do seu. Logo, a mulher precisa ser mutilada, cortada em partes, a fim de que se torne interessante o suficiente para entrar no mundo da significação. Note-se, porém, que aqui não estamos falando da multiplicidade do corpo feminino; expressamos a sua mutilação, dilaceração. Ele é dividido pelo homem (não múltiplo de sentidos e gozo da mulher). Não haveria, pois, a mulher como unidade, e sim como o que falta. Não haveria dois sexos (o homem e a mulher), e sim apenas um: o homem e o não homem.

A mulher não teria um lugar de prazer a não ser aquele que 
o homem desejasse lhe conferir. Ou seja, "a mulher não tem inconsciente, exceto aquele que o homem lhe confere" (IRIGARAY, 1985, p. 93-94). A sexualidade da mulher, em última instância, além de ser pautada na única possível - a masculina - depende exclusivamente da intervenção do homem para que aconteça. E esse desejo do homem é o desejo de ter a mãe, o útero da mãe, possuir a origem de si, permitindo-se continuar.

Mulher como útero, o útero inconsciente da linguagem do homem: por si própria, ela não teria relação com o "seu" inconsciente, exceto aquele que seria marcado por uma desapropriação essencial. Na falta, no êxtase... e no silêncio. (IRIGARAY, 1985, p. 94).

Apenas no papel de mãe, através da gestação e de ter suas crianças, a mulher consegue se inserir novamente nessa sociedade masculina. A mulher está livre (?) das relações e realizações sexuais; não faz parte delas, porque sua única função é ser a mãe - livre de prazeres. Ela é o útero que satisfaz as necessidades masculinas de existência, de linguagem, e através do seu útero os homens lhe conferem a "feminilidade”. Ela é o receptáculo, o cálice, reservatório que garante a continuação masculina - um espaço do homem, enfim.

Dentro dessa lógica falogocêntrica, por meio da qual as mulheres são separadas umas das outras, são analisadas uma a uma, para que lhes seja impossibilitada a noção de um todo uno onde seja possível um novo discurso, uma nova linguagem. "A falta de acesso ao discurso no corpo do Outro é transformada em intervalos que separam todas as mulheres umas das outras" (IRIGARAY, 1985, p.98). Negada à mulher a possibilidade do autoerotismo, ela só sente como o outro - na lógica da mesmidade. Ela, portanto, não tem voz, não tem corpo e não possui a palavra, situação contra a qual se insurge a eu-lírica no poema a seguir. 
FAZER O POEMA

Desfio a poesia

no baraço

do peito

Na curva da cintura

em fogo-fátuo

Pois na cama

é poema e é papel

Para logo ser

gemido

corpo e queira

Chegar na palavra

e naquilo que rasgo

Verso a verso ao topo

do orgasmo

(HORTA, 2012, p. 275).

No poema acima, a eu-lírica reclama o local da linguagem e do corpo como presença. Nesse processo, desafia a lógica masculina do discurso ao desfiar a própria poesia que existe dentro de si, e este é um desafio que se encarna no corpo - é a poesia manifestação de seu autoerotismo, dando-se no espaço da cama e do papel. Desafiar a poesia se torna, então, uma atividade vital e orgânica, busca de algo que se confunde com a chegada e o orgasmo, gozo de quem seguiu "verso a verso ao topo" em busca do "gemido/corpo e queira" do poema.

Encontrar a poesia em si é resistir às imposições de ordem masculina, o que só pode se dar na luta e na lida com a linguagem, em que se "desfi[a] a poesia/no baraço do peito". Note-se, nesse verso, a ambiguidade do substantivo "baraço", que pode significar tanto um cordel mais espesso de fios do qual se desenleia a poesia quanto um relho para açoite ou uma corda para enforcamento (HOUAISS, 
2009), o que torna ainda mais dramática a busca tematizada no verso.

A eu-lírica desafia a poesia numa necessidade de encontrar sua própria voz, que não é tomada pela linguagem masculina. Para isso, é necessário ao mesmo tempo revelar a total articulação da mulher com sua linguagem - uma linguagem que fica repleta de vazios e de incompletudes. Estes só podem ser preenchidos com o corpo, quando, "na curva da cintura", a escuridão (ou ausência) devém brilho (ou presença), iluminada pelo fogo fátuo da segunda estrofe.

A sexualidade intrincada nesse processo transforma o poema e a sua matéria de permanência - o papel - em local de prazer, pois na cama se transformam em gemidos as palavras da poesia. Mais uma vez, o prazer feminino se faz múltiplo, se transforma e toma para si todos os espaços que lhe são palpáveis. Ao chegar a essa palavra, aquela que a define, que lhe dá nome, a mulher rasga tudo, transforma o verso a partir da sua fúria e da sua necessidade de não definição no mundo falogocêntrico.

A palavra não é suficiente para expressar-se, para dizer do seu gozo; por isso, a mulher desfaz-se dela. Nessa rebeldia e nessa não definição a partir do masculino, o orgasmo feminino se alcança. Através da sua linguagem e do domínio dela, em paralelo à recusa ao logos fálico, a mulher encontra mais um ponto de prazer. Suas margens não são definidas e o gozo se manifesta em tudo o que a mulher faz, refaz e não faz. A escrita se torna local de prazer - é poema e é papel - e possibilita a permanência material de uma marca do feminino, que se deixa ver desde a conformação morfológica do corpo.

Quando Irigaray (1985) discute o que seria a linguagem feminina, assevera que esta está completamente ligada à corporeidade; contudo, a autora apresenta a impossibilidade de definição do que seja exatamente essa linguagem. Afinal, ao defini-la usando uma sintaxe e um léxico caros à Teoria da Literatura ou da Linguística, instituições sobretudo acadêmicas, mais uma vez estaríamos no reino da tradição e do falogocentrismo, aprisionando a significação sob um ditame machista do signo. 
O que se pode dizer, então, é que a escrita feminina se entrevê mais por sua constante transformação numa economia da fluidez do que por sua materialidade do significante, como nos poemas de Maria Teresa Horta aqui analisados. 0 falar (como) mulher pode ser observado quando há sofrimento (momento em que a mulher se entrega a si mesma), mas também quando há risada e quando a mulher se encontra entre mulheres (IRIGARAY, 1985) e o discurso corre, livre, nos meandros do corpo. Nesses momentos, pode haver a possibilidade de um distanciamento da linguagem masculina para uma apropriação da imanência da voz, da fala da mulher.

Mas escrever nessa sintaxe, nessa fluidez - que é muito próxima à da fala -, é algo que requer uma disciplina muito intensa - uma disciplina no sentido de se libertar de todas as imagens do "reino do imaginário masculino" (IRIGARAY, 1985, p. 135). Nesse sentido, a escrita feminina ressoa justamente no não dito, na fenda - neste intervalo onde a mulher se diferencia do homem e não significa a partir dele. Como todo corte, esse precisa ser aberto - e assim mantido - à custa de uma violência; talho que é, exige uma incisão linguageira no simbólico para fazer esvair e fluir o sentido do ser mulher.

\section{VIOLÊNCIA}

Ó secreta violência

dos meus sentidos domados

em mim parto

e em mim esqueço

senhora do meu

silêncio

com tantos quartos fechados

Anoitece e desguarneço

despeço

aquilo que faço 
Ó semelhança firmeza

mulher doente de afagos

(HORTA, 2007, p. 61).

Neste poema de Maria Teresa Horta, a violência que lhe dá título é também interlocutora, a que a eu-lírica se dirige por meio de dois apóstrofes: "Ó secreta violência/dos meus sentidos domados" e "Ó semelhança firmeza/mulher doente de afagos". Mais do que medo, trata-se de violência que dá segurança, pois a mulher aqui não é vítima do ato violento; trata-se da violência que a mulher perpetra para se afirmar na linguagem, por meio de um corte que lhe abre um espaço para ser.

Ademais, é essa violência que escoria a superfície textual, abrindo-lhe intervalos entre as palavras e os versos, para que a mulher possa significar. Esta se inscreve violentamente no desejo do corpo a fim de libertar seus "sentidos domados" - libido que o patriarcado silencia sob a imagem da mãe virgem. Nesse sequestro de seu gozo, a mulher entra num jogo de "máscaras" (masquerade), em que a realidade acaba sendo invertida e o jogo se torna o que é real, de modo que aquilo que seria essencialmente feminino é perdido e deixado de fora do discurso. Mas é exatamente nesse silêncio que a mulher recupera sua feminilidade, pois ela se entende ainda que continue trancafiada: "senhora do meu/silêncio/com tantos quartos fechados".

Quando se encontra sozinha, ela se liberta das amarras da sintaxe masculina e consegue se sentir e se entender como mulher, o que culmina poeticamente no texto acima em construções estranhas à sintaxe padrão - mas altamente significativas -, como a justaposição de "semelhança firmeza" ou a locução "em mim parto". Nesse processo de autoconhecimento na solidão e no vazio, a mulher se lança em uma jornada cada vez mais para dentro de si, denotada pelos verbos "partir" e "despedir", abrindo sua jornada, à força, no próprio corpo. Essa é a violência da escrita feminina, ou do falar (como) mulher. 
Cixous (2007) também enxerga na escrita o caminho para que a mulher se apodere de seu próprio corpo: "Escreva! Escrever é para você, você é para você, o seu corpo é seu, apodere-se dele" (CIXOUS, 2007, p. 320). A esse respeito, a autora assevera que, apesar de a escrita da mulher não vir a público no passado, ela já escrevia, assim como se masturbava silenciosamente, no espaço do "escondido". Tal qual o orgasmo, a escrita lhe proporcionava o sentimento de culpa, co-habitando o território do interdito.

O erótico, segundo Lorde (1984), está presente em todos os aspectos da nossa vida e negá-lo é perder a capacidade de ser plena, de se conhecer e ser feliz. Render-se a um estigma ou a uma imposição sobre o corpo é não poder gozar e se entregar ao pornográfico - ter o desejo usado por outro. Logo, a escrita também deve apoderar-se do uso do erótico e, através desse corpo que fala (e canta e dança e grita e ri!), ela pode se tornar feminina, desde que não siga reproduzindo o corpo confinado na mentalidade falocêntrica.

É a partir da sua escrita, como assevera Cixous (2007), que a mulher recupera o corpo que lhe foi confiscado. Ela se reconecta com sua própria sexualidade e se torna uma guerreira de si mesma, ao invés de lutar por uma batalha que não é sua. A escrita feminina como escrita do corpo é uma forma de empoderamento feminino que leva a mulher a se apropriar de seu discurso e fazê-lo político.

A mulher fala de si e para si, fala com outras mulheres numa linguagem sua e que não é compreensível para o homem, pois ela está fora da linguagem - é a "não-toda" - e fala com o corpo. Suas palavras são "balbucios" e nesse sentido se aproximam da fala da criança para quem o som e sua articulação com o corpo têm um significado que vai além da linguagem oral (BRANCO; BRANDÃO, 2004). Sua fala faz parte de uma linguagem pré-verbal, e essa reaproximação com um caráter originário da fala e da língua, em que as palavras recobram a corporeidade da enunciação, sublinha o estatuto poético da escrita feminina.

É nessa fala pré-verbal e corporal que a escrita feminina falará 
do corpo da mulher, através do corpo da mulher. Transferir essa linguagem, esse falar (como) mulher, para a obra escrita é levar ao nível do incompreensível a palavra grafada, é transformar a palavra para ressignificar o corpo feminino "E é no momento em que a linguagem verbal se cala que o corpo da personagem invade a cena, por meio da tentativa exaustiva da narradora de reconstituílo, de restaurá-lo." (BRANCO; BRANDÃO, 2004, p.153). Aqui, se substituída a voz enunciadora da narração (narradora) pela voz enunciadora do poema (eu-lírica), pode-se entender como Maria Teresa Horta se torna todas as mulheres ao assumir o lócus de instância poética, dizendo de uma experiência que a transcende e a constitui.

Nesse processo, a escrita feminina não pretende comunicar, ela reivindica ser. Não há mensagem a ser passada, não há signos a serem decifrados: o corpo se diz, não informa. Ele expressa a si na linguagem feminina sem pretender com isso ser entendido intransitividade da literatura de que Barthes (1994) já falara. A multiplicidade da Outra mulher transcende o seu corpo e abarca tudo o que a voz lírica enuncia. Assim, a escrita feminina almeja "ao lado de um sujeito que não chega a ser, à margem de um discurso que não visa a comunicar, em torno de uma escrita - inscrição que pretende dizer o indizível." (BRANCO; BRANDÃO, 2004, p.157). Aporética, essa inscrição melhor se faz na metáfora do poema do que no discurso acadêmico; logo, recorramos à lira de Maria Teresa Horta para experimentar a escrita feminina em ato.

\author{
ANTECIPAÇÃO \\ Entreabro as minhas \\ coxas \\ no início dos teus beijos \\ imagino as tuas \\ pernas \\ guiadas pelo desejo
}




\author{
oiço baixo o teu \\ gemido \\ calado pelos meus dentes \\ imagino a tua boca \\ rasgada \\ sobre o meu ventre \\ (HORTA, 2007, p. 74)
}

A pré-linguagem coabita o espaço da antecipação: é o prenúncio na pele do que vai acontecer. Nesse processo de adivinhar o que virá a ser, a eu-lírica habita o corpo de desejo e as sensações provocadas pela antecipação - tal qual o título que precede, suscita, mas não define o corpo do poema. Mais do que palavras, "Antecipação" vai desabrochando sensações múltiplas que não se concentram num órgão - ou verso - específico. É com o corpo inteiro que a eu-lírica sente: são as coxas ligadas ao beijo, a boca que conduz pelas pernas, o desejo que se mistura com a audição, o gemido que vem da região do indizível, daquilo que é apenas som - e não significante -, mas que é calado pela corporalidade dos dentes.

Nesse poema, a linguagem não é matéria-prima da imagem; ela é construída como imagem do corpo. 0 enjambement entre os versos é então articulação sintática e anatômica, com que a falta de sinais de pontuação colabora, sugerindo a fluidez e a circularidade do desejo feminino, sem entraves. Se o desejo não reconhece limites, não deve também a linguagem estabelecê-los, de modo que só como pré-linguagem - infensa à castração ou à adoração do falo - pode a escrita feminina se construir. Gemido calado, imaginado, é sempre significação fugidia, condição do sentido que não se quer absoluto.

A imaginação presente desce até o ventre. Através da palavra escrita, sente-se a pulsação do desejo que, antevisto ainda na esfera da não presença, já faz gemer. É "um gozo de um corpo que goza a si mesmo" (GABRIEL, 2009, p. 47).

Essa escrita feminina que se faz impossível de ser captada, domada e classificada é justamente ferramenta do indizível da 
mulher, aqui analisada na pena de Maria Teresa Horta. Trata-se, pois, de feminino que não pode ser contido em um quarto escuro, que não teme a lacuna e que é turbilhão lírico: letra, corpo e gozo.

\section{Considerações finais}

A escrita feminina não se quer passível de uma apreensão final de significado ou de uma definição que circunscreva seus limites estéticos, até porque delimitar e segregar são estratégias do patriarcado que marginalizaram, ao longo dos séculos a mulher. É como gozo, sempre inefável e fugidio, que essa linguagem deve ser entendida, cabendo-nos sobretudo fruí-la para melhor entendê-la, como aqui fazemos no diálogo entre a teoria feminista e a lira de Maria Teresa Horta.

Na produção poética da autora portuguesa, observamos a ressignificação do ser mulher, como sujeito de seu corpo e seus desejos, perquiridos numa busca de si no seio da poesia. Sua escrita feminina, construída não como negativa do masculino - e sim como afirmação de mulher -, enseja uma série de reflexões teóricas, que se buscou alinhavar no presente artigo.

À guisa de conclusão, encerra-se aqui o fio argumentativo, mas na ciência de que todo fim ou divisa é arbitrário, como bem nos ensina o feminismo. Na superação dos limites, o ser mulher transborda as fronteiras estipuladas pelo falocentrismo e por isso sua escrita se torna subversiva. Ela usa as ferramentas masculinas e de dentro delas faz com que suas bordas sejam alargadas, remodeladas, e isso tudo para transcendê-las. A mulher múltipla não teme o abismo que o falocentrismo lhe atribuiu por se saber transbordante.

Nós somos tempestuosas, e isto que é nosso se liberta de nós sem nosso temor de alguma debilidade. Nossos olhares, nossos sorrisos são gastos; risadas exsudam de nossas bocas; nosso sangue flui e nós nos estendemos sem jamais alcançar um fim; nós nunca seguramos nossos pensamentos, nossos signos, nossa escrita; e nós não temos medo da falta. (CIXOUS, 2007, p. 322). 
Dessa forma a mulher fala, Maria Teresa Horta fala e a eu-lírica devém nós-líricas: uma mulher é sempre todas as mulheres.

\section{Referências bibliográficas}

BARRENO, M. I.; COSTA, M. V.; HORTA, M. T. Novas cartas portuguesas. São Paulo: Abril (Círculo do Livro), 1974.

BARTHES, R. Aula. São Paulo: Cultrix, 1994.

. Crítica e verdade. São Paulo: Perspectiva, 2011.

BEAUVOIR, S. de. 0 segundo sexo. v.I, II. Rio de Janeiro: Nova Fronteira, 1980.

BRANCO, L. C.; BRANDÃO, R. S. A mulher escrita. Rio de Janeiro: Lamparina editora, 2004.

CIXOUS, H. The Laugh of the Medusa. In.: FREEDMAN, S. B. The essential feminist reader. New York: Modern Library. 2007.

. The newly born woman. Minneapolis: University of Minnesotta Press, 1987.

DERRIDA, J. Dissemination. Chicago: University of Chicago Press, 1981.

GABRIEL, A. B. A casa da diferença. 106 f. Monografia (Mestrado em Filosofia). Instituto de Humanidades. Universidade de Brasília. Brasília. 2009. 
HORTA, M. T. As Palavras do Corpo (Antologia de Poesia Erótica). Lisboa: Publicações Dom Quixote, 2012.

. Minha Senhora de Mim. Lisboa: D. Quixote, 1971.

. Palavras Secretas. São Paulo: Escrituras Editora, 2007.

Poesia Completa. Lisboa: Litexa, v.1 e 2, 1983.

HOUAISS, A. HOUAISS eletrônico. Versão Monosuário 3.0. Editora Objetiva, 2009.

IRIGARAY, L. 0 gesto da psicanálise. In.: BRENNAN, Teresa (org). Para além do falo: uma crítica a Lacan do ponto de vista da mulher. Rio de Janeiro: Record/Rosa dos Tempos, 1997.

This sex which is not one. Ithaca, New York: Cornell University Press. 1985

LORDE, A. Uses of the Erotic: The Erotic as Power, In: Sisters Outsider: essays and speeches. New York: The Crossing Press Feminist Series, 1984. P. 53-594.

SPIVAK, G. C. 1988b. 'Can the Subaltern Speak?' in. Nelson C. and Grossberg, L. (eds.) Marxism and the Interpretation of Culture. London: Macmillan, pp. 271 - 313. 